Volume 11 Nomor 1, November 2019, p. 114 - 131

Faculty of Law, Universitas Kristen Maranatha

ISSN: 2085-9945 I e-ISSN: 2579-3520

Nationally Accredited Journal by SINTA

\title{
DISKRIMINASI HUKUM DALAM PEMBERANTASAN KORUPSI POLITIK DI DAERAH
}

\author{
1. Jupri
}

Fakultas Hukum, Universitas Ichsan Gorontalo

\section{Roy Marthen Moonti}

Fakultas Hukum, Universitas Gorontalo

roymoonti16@gmail.com

Submitted: 2019-10-23 | Reviewed: 2019-11-11 | Accepted: 2019-11-19

\begin{abstract}
Corruption is an act to against the law and moral because it is considered as an act abusing the power and authority for personal's benefit, group or other parties to take advantage each other either economically or politically. Due to perpetrators of corruption is a public official, the type of corruption is considered as political corruption. One of many cases of political corruption in regional level is corruption on social assistance fund. The reality of social assistance fund corruption case disclosure in many regionals seems difficult. The sociology aspect takes a part in law enforcement such as stratification, morphology and intervention variables. Stratification which is a formal position of somebody, friendship between law enforcers and the suspect, and intervention of superior to the subordinate in legal institution confirm the legal discrimination in corruption act of social assistance fund. Therefore, to suppress the rate of corrupt behavior in regional level, it needs the legal enforcement reconstruction started from legal enforcer side to the encouragement of legal enforcer reformation in regional level. The legal enforcer reformation should emphasize on the importance of rolling job system at the top management in the legal enforcement institution. This system can enrich experience and perception, and to sharpen the skills. On the other hand, it can minimize the occurrence of morphology aspect between the legal enforcer and local elites. Besides, the involvement of justice collaborator in corruption eradication should be implemented in order to reveal the political corruption case which is complicated and neatly covered.
\end{abstract}

Keywords: Corruption Eradication Reconstruction Discrimination; Political Corruption. 
Dialogia luridica: Jurnal Hukum Bisnis dan Investasi

Vol. 11 (1): 114-131

\section{PENDAHULUAN}

Pembentukan suatu negara pada prinsipnya menghendaki terciptanya kemakmuran bagi seluruh rakyat. Hal ini ditegaskan dalam Pembukaan Undang-Undang Dasar Negara Kesatuan Republik Indonesia 1945 bahwa "kemudian dari pada itu untuk membentuk suatu pemerintahan Negara Indonesia yang melindungi segenap bangsa Indonesia dan seluruh tumpah darah Indonesia dan memajukan kesejahteraan umum, mencerdaskan kehidupan bangsa dan ikut melaksanakan ketertiban dunia yang berdasarkan kemerdekaan, perdamaian abadi dan keadilan sosial".

Tujuan yang termaktub dalampembukaan UUD NKRI 1945 akan terwujud jika bangsa Indonesia dapat memanfaatkan segala potensi yang dimilikinya secara maksimal. Namun berbagai faktor menyebabkan upaya mewujudkan tujuan mulia itu menghadapi banyak kendala. Berbagai hasil penelitian menunjukkan bahwa masyarakat memandang korupsi sebagai permasalahan utama bangsa yang perlu segera diatasi. ${ }^{1}$

Robert Klitgaard melahirkan rumus $(\mathrm{C}=\mathrm{M}+\mathrm{D}-\mathrm{A})$ untuk mendefinisikan kata "korupsi". Dimana kurang lebih menyatakan bahwa korupsi adalah Monopoly digabungkan dengan kewenangan penentuan kebijakan (Discretion)dan kurang pertanggungjawaban (Accountability). Sejalan dengan ungkapan Lord Acton "power tends to corrupt, and absolute power corrupts absolutely" atau kekuasaan/kewenangan cenderung disalahgunakan. Kedua pernyataan ini, mengkonfirmasi betapa kekuasaan sangatlah dekat dengan perilaku korupsi.

Korupsi kekuasaan merupakan penyelewengan kekuasaan yang mengarah pada tidak berjalannya fungsi kekuasaan sebagaimana mestinya. Misalnya, pembuatan kebijakan yang salah (atau sengaja dibuat salah), pelayanan yang tidak maksimal atau memalingkan fungsi kebijakan sebagai bentuk pelayanan kepada rakyat menjadi kebijakan yang tidak berpihak kepada rakyat. Korupsi jenis ini seringkali tidak terdeteksi meski dampaknya sangat luas terhadap eksistensi bangsa dan negara. Korupsi kekuasaan menjadi sumber lahirnya korupsi konvensional yang berkaitan dengan kejahatan keuangan. selain korupsi model ini, kita biasa mendengar pula istilah korupsi politik. ${ }^{2}$

\footnotetext{
${ }^{1}$ KPK, Delapan Agenda Antikorupsi Bagi Presiden 2014-2019, Jakarta: Penerbit KPK, 2014, hlm. 8.

${ }^{2}$ Jupri, KPK \& Korupsi Kekuasaan, Malang: Pusat Kajian Inovasi Pemerintahan dan Kerjasama Antar Daerah Program Studi Ilmu Pemerintahann FISIP Universitas Brawijaya. 2016, hlm. 1.
} 
Dialogia luridica: Jurnal Hukum Bisnis dan Investasi

Vol. 11 (1): 114-131

Lebih jauh terkait korupsi politik didefinisikan Artidjo Alkostar sebagai suatu tindakan yang dilakukan oleh elit politik atau pejabat pemerintahan negara yang memiliki dampak terhadap keadaan politik dan ekonomi negara. Perbuatan ini biasanya dilakukan oleh orang-orang dan atau pihak-pihak yang memiliki jabatan atau posisi politik. Korupsi politik ini bisa dilakukan oleh Presiden, kepala pemerintahan, para Menteri suatu kabinet yang pada dasarnya memiliki jabatan politis, anggota parlemen, dapat dikualifikasi sebagai korupsi politik, karena perbuatan itu dilakukan dengan mempergunakan fasilitas atau kemudahan politis yang dipunyai oleh pelaku. Fasilitas yang disalahgunakan tersebut pada dasarnya merupakan amanat atau kepercayaan yang diberikan oleh rakyat. ${ }^{3}$ Model korupsi politik adalah the mother of corruption meminjam istilah Teten masduki. Merupakan induk dari perilaku koruptif yang marak terjadi di Indonesia, selain korupsi di bidang hukum.

Korupsi politik yang marak terjadi di daerah menguat bertepatan dengan proyek desentralisasi yang memberikan kewenangan pemerintah daerah semakin besar. Dan, harus diingat bahwa kekuasaan yang besar merupakan sumber korupsi. ${ }^{4}$ Betapa korupsi politik begitu marak terjadi di Indonesia, terkonfirmasi dari pernyataan Menteri Dalam Negeri Tjahyo Kumolo dalam pelaksanaan Puncak Peringatakan Hari Anti Korupsi Internasional, menyatakan tahun 2004-2017 terdapat 392 kepala daerah tersangkut hukum, jumlah terbesar adalah korupsi sejumlah 313 kasus. ${ }^{5}$ Artinya politik desentralisasi yang pada prinsipnya memberikan kewenangan besar kepada pemerintah daerah untuk mengurus daerahnya sendiri serta bertujuan mempercepat pemerataan pembangunan, justru melahirkan 'Raja-Raja” kecil.

Bila dilacak secara saksama ternyata ada banyak faktor penyebab para pejabat daerah dalam melakukan tindakan korupsi. Pertama, para pejabat politik di daerah berlombalomba mengumpulkan pundi-pundi untuk digunakan sebagai money politics dalam ajang pemilihan legislatif dan pemilihan kepala daerah. Mereka dengan culas memanfaatkan kemiskinan rakyat untuk membeli suara. Mereka tidak mau susah payah melakukan kerjakerja politik dan sosial untuk merebut hari rakyat. Kedua, korupsi politik yang dilakukan pejabat daerah sangat berkaitan dengan patronase demokrasi, yakni "hubungan antara

\footnotetext{
${ }^{3}$ Ibid, hlm. 2.

${ }^{4}$ Muhtar Haboddin, dkk, Memahami Kompleksitas Korupsi, Akar, Implikasi dan Solusi, Malang: FISIP Press Universitas Brawijaya, 2016, hlm. 37.

${ }^{5}$ Lihat Jawa Pos, 11 Desember 2017.
} 
Dialogia luridica: Jurnal Hukum Bisnis dan Investasi

Vol. 11 (1): 114-131

orang memegang jabatan politik dengan orang yang memiliki kekayaan dan kepentingan bisnis. Pelaku bisnis memberikan dana kepada pejabat publik agar memggunakan wewenangan dan pengaruhnya untuk menguntungkan pelaku bisnis". Selama pelaksanaan politik desentralisasi korupsi politik menjadi sumber dari segala korupsi di daerah. Dari korupsi politik, muncul turunan-turunan korupsi yang dilakukan pegawai negeri sipil dan aparat birokrasi dengan modus pemberian uang pelicin. Ketiga, desentralisasi pemerintahan telah memberikan kekuasaan yang besar kepada pejabat daerah dalam mengelola pemerintahan daerah. Kekuasaan yang besar ini sangat rawang disalahgunakan oleh pejabat daerah karena tidak diimbangi dengan mekanisme check and balances dari lembaga pemerintah maupun kelompok masyarakat sipil. Keempat, korupsi yang dilakukan para pejabat lokal disebabkan karena kuatnya ikatan parochial dalam pengelolaan pemerintahan. Tak bisa disangkal bahwa korupsi parochial ini termanifestasi dalam pemberian perlakuan istimewa kepada anak-anak, keponakan atau saudara dekat para pejabat. ${ }^{6}$

Korupsi politik telah, sedang dan akan selalu muncul pada habitat kekuasaan yang memiliki hak dan diskresi politik yang luas dan memiliki kesempatan dan sarana untuk menyalahgunakan kekuasaan. Lebih jauh Artidjo menyebut penyebab korupsi politik, yaitu: (1) Nafsu politik untuk mempertahankan dan memperluas kekuasaan, karena kekuasaan adalah kewenangan untuk mengatur kehidupan kewarganegaraan. Terutama kewenangan untuk mendistribusikan ekonomi dan sumber daya alam, serta kekuasaan untuk melaksanakan kebijakan politik. (2) Tersedianya sarana dan fasilitas ekonomi dan politik yang steril dari budaya dialogis. (3) Tidak adanya kontrol efektif dari rakyat. (4) Faktor iklim sosial politik yang krisis keteladanan dan kevakuman moral. (5) Faktor iklim penegak hukum yang tragikomis, dimana kredibilitas penegak hukum merosot, karena adanya krisis institusi dan mental aparat penegak hukum. ${ }^{7}$ Korupsi politik berkorelasi dengan struktur sosial yang feodal kerena memberikan kesempatan bagi timbulnya kevakuman moral, sehingga interaksi sosial tidak berproses secara egaliter.

Kasus korupsi politik yang menjadi sorotan penulis adalah kasus korupsi Dana Hibah dan Bantuan Sosial (Bansos) Jember Tahun 2015 yang merugikan keuangan negara sebesar Rp 38 Miliar. Kasus korupsi tersebut melilit sejumlah nama anggota DPRD

\footnotetext{
${ }^{6}$ Muhtar Haboddin, dkk. op.cit, hlm. 45-47.

${ }^{7}$ Artidjo Alkostar, Korupsi Politik di Negara Modern, Yogykarta: FH UII Press, 2008, hlm. 383.
} 
Dialogia luridica: Jurnal Hukum Bisnis dan Investasi

Vol. 11 (1): 114-131

Jember periode 2014-2019. Dari pihak eksekutif menjerat Sekretaris Daerah Kab. Jember dan Kepala Badan Pengelolaan Keuangan dan Aset Daerah Kab. Jember. Setali tiga uang, korupsi dana Bansos juga terjadi di Bone Bolango yang melibatkan kepala daerah.

Sejalan dengan pernyataan Agus Riwanto bahwa korupsi adalah tindakan melawan hukum dan moral karena menyalahgunakan kekuasaan dan kewenangan yang dimiliki seseorang untuk kepentingan dirinya, kelompok atau pihak-pihak lain untuk saling mencari keuntungan secara ekonomi maupun politik. Karena pelakunya adalah pejabat publik maka perilakunya dapat disebut sebagai korupsi politik (political corruption). ${ }^{8}$

Kasus korupsi dana Bansos di atas, menarik untuk dikaji karena melibatkan elit lokal seperti anggota DPRD dan pihak eksekutif. Selain itu, dari puluhan nama yang disebut turut serta melakukan tindak pidana korupsi sebagaimana dalam putusan Pengadilan Tipikor Surabaya dan sejumlah nama disebutkan dalam putusan Pengadilan Tipikor Gorontalo. Pihak penegak hukum di daerah cenderung memperlihatkan diskriminasi penegakan hukum atau tebang pilih.

Berdasarkan pemaparan yang diuraikan diatas maka dapat ditarik permasalahan yaitu realitas penegakan hukum korupsi politik di daerah dan bagaimana rekonstruksi pemberantasan korupsi politik di daerah.

\section{PEMBAHASAN}

\section{Realitas Penegakan Hukum Korupsi Politik di Daerah}

Salah satu pendekatan yang dapat digunakan untuk melihat bagaimana sulitnya pengungkapan korupsi politik oleh penegak hukum di daerah dengan pendekatan sosiologi hukum. Suatu pendekatan yang mempelajari fenomena hukum bertujuan untuk memberikan penjelasan mengapa dan bagaimana praktik-praktik hukum terjadi, sebabnya, faktor-faktor yang mempengaruhi, latar belakang dan sebagainya.

Menurut Achmad Ali bahwa sosiologi hukum menekankan kajian pada law in action, hukum dalam kenyataannya, hukum sebagai tingkah laku manusia, yang berarti berada di dunia sein. Sosiologi hukum menggunakan pendekatan empiris yang bersifat deskriptif. ${ }^{9}$

\footnotetext{
${ }^{8}$ Agus Riwanto, Desain Sistem Pemerintahan Antikorupsi; Konsep Pencegahan Korupsi Politik dalam Sistem Pemerintahan, Partai Politik dan Pemilu, Malang: Setara Press, 2018, hlm. 21.

${ }_{9}^{9}$ Achmad Ali, Menjelajahi Kajian Empiris Terhadap Hukum, Jakarta: Predana Media, 1998, hlm. 11.
} 
Dialogia luridica: Jurnal Hukum Bisnis dan Investasi

Vol. 11 (1): 114-131

Hukum bukanlah apa yang ada dalam peraturan perundang-undangan, Ia kemudian dikatakan hukum bila telah diterapkan di dalam masyarakat.

Karakteristik kajian atau studi hukum secara sosiologis menurut Satjipto Rahardjo ${ }^{10}$ yaitu Pertama, sosiologi hukum adalah ilmu yang mempelajari fenomena hukum yang bertujuan untuk memberikan penjelasan terhadap praktik-praktik hukum. Sosiologi hukum menjelaskan mengapa dan bagaimana praktik-praktik hukum itu terjadi, sebabsebabnya, faktor-faktor yang berpengaruh, latar belakang dan sebagainya. Kedua, sosiologi hukum senantiasa menguji kesahihan empiris (empirical validity) dari suatu peraturan atau pernyataan hukum. Bagaimana kenyataannya peraturan itu, apakah sesuai dengan bunyi atau teks dari peraturan itu. Ketiga, sosiologi hukum tidak melakukan penilaian terhadap hukum. Tingkah laku yang mentaati hukum dan menyimpang dari hukum sama-sama merupakan objek pengamatan yang setaraf. Sosiologi hukum tidak menilai antara satu dengan yang lain, perhatian yang utama dari sosiologi hukum hanyalah pada memberikan penjelasan atau gambaran terhadapa objek yang dipelajarinya.

Sosiologi hukum memperkenalkan banyak faktor-faktor non hukum yang mempengaruhi perilaku hukum tentang bagaimana mereka mereka membentuk dan melaksanakan hukum. Dalam ini sosiologi hukum menekankan pada penerapan hukum secara wajar atau patut, yaitu memahami aturan hukum sebagai penuntun umum bagi aparat penegak hukum. Salah satu teori sosiologi hukum yang tepat melihat perselingkuhan penegak hukum dengan elit lokal yakni teori Perilaku hukum (behavior of law) yang diperkenalkan Donald Black.

Teori ini memperkenalkan aspek variabel/ indikator yang menimbulkan diskriminasi hukum. Pertama, stratifikasi yaitu aspek vertikal dari kehidupan sosial, atau setiap distribusi yang tidak seimbang dari kondisi-kondisi yang ada, seperti makanan, aspek ke tanah atau air dan uang. Kedua, morfologi yaitu aspek horizontal, atau distribusi dari orang dalam hubungannya dengan orang lain, termasuk pembagian kerja di antara mereka, integrasi dan keakraban yang berlangsung diantara mereka. Ketiga, kultur yaitu aspek simbolik, seperti religi, dekorasi dan folkor. Keempat, Organisasi yaitu aspek korporasi, atau kapanilitas bagi tindakan kolektif. Kelima, pengendalian sosial (social

\footnotetext{
${ }^{10}$ Satjipto Rahardjo, Faktor-Faktor yang Mempengaruhi Penegakan Hukum, Jakarta: Rajawali, 1986, hlm.
} 310-311. 
Dialogia luridica: Jurnal Hukum Bisnis dan Investasi

Vol. 11 (1): 114-131

control) yaitu aspek normatif dari kehidupan sosial, atau definisi tentang perilaku yang menyimpang dan tanggapan terhadapnya, seperti larangan, dakwaan, pemidanaan dan kompensasi.

Aspek variabel ini kemudian, Penulis gunakan untuk menganalisis Kasus Korupsi Politik di daerah yakni Kasus Dana Hibah dan Bansos Jember 2015 dan Kasus Bansos Bone Bolango Provinsi Gorontalo. Seiring perkembangan pengungkapan tindak pidana korupsi (Hibah dan Bansos Jember) yang merugikan keuangan negara sebesar Rp.38 Miliar. Pihak-pihak yang terlibat maupun yang disebut terlibat dalam korupsi politik Dana Hibah dan Bansos Jember adalah sejumlah nama anggota legislatif DPRD Kab. Jember periode 2014-2019. Modus yang dilakukan yakni dengan cara pembentukan kelompok penerima yang sebagian disinyalir fiktif, pengajuan proposal yang tidak sesuai dengan prosedur Surat Edaran Mendagri Nomor 39 Tahun 2012 tentang Pedoman Pemberian Hibah dan Bansos yang bersumber dari APBD, penyimpangan pelaksanaan di lapangan yang tidak sesuai dengan proposal pengajuannya dan tidak adanya pertanggungjawaban dalam penggunaan anggaran bantuan Hibah dan Bansos. Adapun pihak-pihak yang terkait dapat dirinci sebagai berikut:

Tabel 1.

Pihak-pihak yang terlibat maupun yang disebut terlibat dalam korupsi politik Dana Hibah dan Bansos Jember 2015

\begin{tabular}{|c|l|c|c|}
\hline No & \multicolumn{1}{|c|}{ Nama } & Pekerjaan & Keterangan \\
\hline 1 & Sugiarto & $\begin{array}{r}\text { Kabag Pegelolaan Keuangan } \\
\text { dan Aset Daerah Jember }\end{array}$ & Terpidana \\
\hline 2 & Ita Poeri Andayani & Ketua DPRD Jember & Terpidana \\
\hline 3 & Thoif Zamroni & Anggota DPRD Jember & Terpidana \\
\hline 4 & Wahid Saini & Anggota DPRD Jember & Terpidana \\
\hline 5 & Kusnadi & & Belum \\
\hline 5 & Ayub Junaedi & Bupatil Ketua DPRD Jember & - \\
\hline 6 & MZA Djalal & Wakil Ketua DPRD Jember & - \\
\hline 7 & Ni Nyoman Putu Martini & Wakil Ketua DPRD Jember & - \\
\hline 8 & Yuli Priyanto & Anggota DPRD Jember & - \\
\hline 9 & 44 Orang &
\end{tabular}


Dialogia luridica: Jurnal Hukum Bisnis dan Investasi

Vol. 11 (1): 114-131

Sumber: Putusan dan Berbagai Media, diolah 2019.

Berdasarkan tabel 1 di atas, penegakan hukum tindak pidana korupsi yakni Dana Hibah dan Bantuan Sosial (Bansos) Jember tahun 2015 yang merugikan keuangan negara Rp. 38 Miliar belumlah maksimal. Terkonfirmasi dari Putusan Pengadilan Tipikor Surabaya untuk terdakwa Thoif Zamroni terbukti secara bersama melakukan tindak pidana korupsi dengan seluruh unsur pimpinan dan anggota DPRD Jember periode 20142019 berjumlah 50 (lima puluh) orang. Akan tetapi, faktanya dari unsur legislatif hanya 3 (tiga) orang yang diperiksa di muka pengadilan. Sedangkan unsur eksekutif hanya Sugiarto selaku Sekretaris Daerah Jember dan Ita Poeri Andayani selaku Kabag Pengelolaan Keuangan dan Aset Daerah Jember yang ditetapkan sebagai tersangka kemudian menjalani masa pidana. Padahal Putusan Nomor 177/Pid.SusTPK/2018/PN.SBY atas nama terdakwa Ita Poeri Andayani berdasarkan fakta persidangan terlihat adanya peran aktif Bupati Jember MZA Djalal.

Ketidaktuntasan pengungkapan kasus korupsi Dana Hibah dan Bansos Jember 2015 sebagaimana Teori Perilaku Hukum Donald Black, bahwa ada sejumlah variabel yang berpengaruh atas lahirnya diskriminasi penegakan hukum, yakni Status Sosial (Stratification) dan Morfologi. Keseluruhan faktor ini berkaitan dengan faktor eksternal dari aparat penegak hukum, karena kondisi sosiologi dapat berpengaruh terhadap tindakan aktor-aktor atau penegak hukum, terutama penyidik dalam menetapkan tersangka.

\section{Faktor Status Sosial (Stratification)}

Stratifikasi atau status sosial yang dimaksud dalam tulisan ini adalah kedudukan sosial seseorang dalam masyarakat baik tokoh formal maupun informal dan lebih jauh melihat posisi Jabatan dan kekuatan politik masing-masing. Selanjutnya akan dianalisis apakah stratifikasi pihak-pihak yang disebutkan dalam kasus Dana Hibah dan Bansos Jember 2015 berpengaruh terhadap penegakan hukum yang dilakukan oleh Kejaksaan Tinggi Jawa Timur.

Musakkir ${ }^{11}$ dalam sebuah penelitian pengaruh aspek sosial terhadap lahirnya putusan Hakim yang Diskriminatif menyatakan bahwa pengaruh status sosial

\footnotetext{
${ }^{11}$ Musakkir, Putusan Hakim Yang Diskriminatif dalam Perkara Pidana; Suatu Tinjauan Sosiologi Hukum dan Psikologi Hukum, Yogyakarta: Rangkang Education, 2013, hlm. 179-180.
} 
terhadapnya lahirnya putusan hakim yang diskriminatif menunjukkan diantara 80 (delapan puluh) orang penegak hukum dan warga masyarakat, terdapat 59 (lima puluh sembilan) orang (73.8\%) yang menilai bahwa status sosial tersangka atau terdakwa dan saksi korban berpengaruh terhadap lahirnya putusan hakim yang diskriminatif, sementara terdapat 21 (dua puluh satu) orang (26,2\%) menyatakan bahwa tidak berpengaruh. Demikian pula, pandangan beberapa perwakilan penegak hukum dan warga masyarakat yang diperoleh melalui wawancara. Bahwa pandangan penyidik dan jaksa penuntut umum dalam menilai pengaruh status sosial tersangka atau terdakwa, dan saksi korban terhadap lahirnya putusan hakim yang diskriminatif, menyatakan bahwa dalam realitas relatif terjadi penanganan atau perlakuan yang berbeda pada setiap tersangka atau saksi korban yang memiliki status sosial yang tinggi dengan yang rendah. Namun, tetap diupayakan untuk memperoleh perlakuan yang sama.

Melihat penegakan hukum kasus Dana Hibah dan Bansos Jember 2015, pun terlihat hal yang sama walaupun penulis melihat dari konteks pemeriksaan pada tahap pra adjudikasi yang dilakukan oleh Kejaksaan Tinggi Jawa Timur. Tinggi rendahnya status sosial atau jabatan sangat berpengaruh terhadap kapan akan dilakukan penetapan tersangka. Terkonfirmasi dari penetapan tersangka Sugiarto selaku Sekretaris Daerah Jember dan Ita Poeri Andayani selaku Kabag Pengelolaan Keuangan dan Aset Daerah Jember. Sedangkan Bupati Jember MZA Djalal hanya diperiksa sebagai saksi. Di saat yang sama, unsur legislatif pun dari 50 (lima puluh) orang anggota DPRD Jember hanya 3 (tiga) orang yang ditetapkan sebagai tersangka. Padahal berdasarkan fakta persidangan semua anggota DPRD Jember menerima Dana Hibah dan Bansos Jember 2015. Masing-masing unsur pimpinan DPRD sebesar Rp 1 Miliar lebih, dan seluruh anggota sebesar Rp 900.000.000 (sembilan ratus juta rupiah).

Pengaruh variabel status sosial juga terkonfirmasi dalam penanganan kasus Bansos APBD Bone Bolango Tahun 2011-2012. Terlihat adanya perbedaan perlakuan antara tersangka Yuldiawati Kadir dan Slamet Wiardi dengan tersangka Hamim Pou selaku Bupati dimana terjadi pengambialihan yang awalnya ditangani Kejaksanaan Negeri Suwawa ke Kejaksaan Tinggi Gorontalo. Dimana jabatan Yuldiawati Kadr selaku Bendahara Bantuan pada Dinas Pendapatan dan Pengelolaan Keuangan dan 
Dialogia luridica: Jurnal Hukum Bisnis dan Investasi

Vol. 11 (1): 114-131

Aset Daerah kabupaten Bone Bolango sekarang menjabat Kepala Sub Bagian Umum dan Kepegawaian pada Badan Penanggulangan Bencana Daerah Kabupaten Bone Bolango, sedangkan Slamet Wiardi sebagai Kepala Badan Keuangan Daerah Bone Bolango. Kedua tersangka ini dilimpahkan ke Pengadilan Tindak Pidana Korupsi Gorontalo, disaat yang sama tersangka Hamim Pou selaku Bupati Bone Bolango sekaligus Ketua Dewan Pimpinan Wilayah Parta Nasdem Provinsi Gorontalo justru diterbitkan Surat Penghentian Penyidikan dan Penuntutan oleh Kejati Gorontalo Nomor 509/R.5/Fd.1/09/2016.

\section{Morfologi}

Morfologi yang dimaksud dalam tulisan ini adalah derajat hubungan emosional, kelembagaan, antar aparat penegak hukum dengan seseorang yang disebut dalam kasus korupsi politik (Dana Bansos). Secara konkrit dapat berupa hubungan persahabatan, kekerabatan, pekerjaan, antara pihak-pihak yang disebut terlibat dalam kasus korupsi dengan aparat penegak hukum. Lebih lanjut Musakkir ${ }^{12}$ menyatakan bahwa pengaruh morfologi terhadap diskriminasi penegak hukum menunjukkan 80 (delapan puluh) penegak hukum dan warga masyarakat, terdapat 54 (lima puluh empat) orang (67,5\%) yang menilai bahwa kedekatan hubungan (morfologi) berpengaruh, sementara terdapat 26 orang $(32,5 \%)$ tidak berpengaruh. Walaupun riset ini melihat aspek sosiologi terhadap putusan penegak hukum yang diskriminatif. Akan tetapi pun terlihat dalam kasus korupsi Dana Bansos Kabupaten Bone Bolango Provinsi Gorontalo.

1. Kasus Korupsi Dana Bansos Bone Bolango Tahun 2011-2012 dengan kerugian negara Rp. 3 Miliar. Pada tahun 2016 Hamin Pou selaku Bupati Bone Bolango ditetapkan tersangka oleh Kejaksaan Negeri Suwawa (sekarang berganti nama menjadi Kejaksaan Negeri Bone Bolango) bersama-sama dengan Yulniawati Kadir dan Slamet Wuliardi dengan Surat Perintah Penyidikan dugaan tindak pidana korupsi Nomor 426/R.5/Fd.1/08/2015. Selanjutnya pada tanggal 6 April 2016 pihak dari tersangka Hamim Pou melakukan upaya Praperadilan atas penetapan tersangkanya di Pengadilan

${ }^{12}$ Musakkir, Ibid, hlm. 184. 
Negeri Gorontalo, akan tetapi ditolak sebagaimana amar putusan Nomor 04/Pidana.Pra/2016/PN.GTO.

2. Tersangka lain yakni Yulniawati Kadir dan tersangka Slamet Wuliardi dilimpah ke Pengadilan Tipikor Gorontalo dan dinyatakan dalam amar putusan Bebas, akan tetapi Kejari Suwawa melakukan upaya hukum Kasasi ke Mahkamah Agung. Berbeda dengan tersangka Hamim Pou selaku Bupati aktif Kabupaten Bone Bolango yang kasusnya ditarik atau diambil alih oleh Kejati Gorontalo, pada tanggal 15 September 2016, Kejati Gorontalo menerbitkan Surat Perintah Penghentian Penyidikan (SP3) Nomor 509/R.5/Fd.1/09/2016.

3. Atas SP3 tersebut, pihak LSM Jamper melakukan upaya permohonan praperadilan sebagaimana Putusan Praperadilan Nomor 10/Pid.Pra Peradilan/2016/PN.GTO akan tetapi status NO karena LSM dinyatakan tidak fokus dalam kajian antikorupsi.

4. Pada tanggal 27 November 2017 Mahkamah Agung mengeluarkan putusan Kasasi oleh Kejari Suwawa atas nama Yuldiawati Kadir Putusan Nomor 59 K/PID.SUS/2017 dalam amar putusan mengabulkan Permohonan Kasasi/ Penuntut Umum Kejari Suwawa dan membatalkan putusan bebas terdakwa sebagaimana putusan Pengadilan Tindak Pidana Korupsi Gorontalo Nomor 9/Pid.Sus-TPK/2016/PN.GTO tanggal 22 Agustus 2016

5. Berdasarkan putuasn kasasi Mahkamah Agung Nomor 59 K/PID.SUS/2017 pihak LSM Jamper, kembali mempraperadilankan SP3 Kejati Gorontalo atas nama Hamim Pou. Pada tanggal 4 Juni 2018 Hakim Tunggal Erwinson Nababa, SH dalam amar putusan menyatakan menerima dan mengabulkan Permohonan Pemohon untuk seluruhnya, memerintahkan kepada Termohon untuk mencabut Surat Penghentian Penyidikan dan Penuntutan (SP3) Nomor; PRINT-509/R.5/Fd.1/09/2016 terhadap tersangka Hamim Pou, memerintahkan termohon untuk melanjutkan penyidikan terhadap tersangka Hamim Pou dan melimpahkan perkara tindak piana korupsi Dan Bansos APBD Bone Bolango tahun 2011-2012 dengan tersangka Hamim Pou kepada Pengadilan. 
Rentetan kronologis kejadian di atas, aspek sosiologis sangat berpengaruh dalam pengungkapan Kasus Korupsi Dana Bansos Bone Bolango.Pertama, terlihat adanya perbedaan perlakuan antara tersangka Yuldiawati Kadir dan Slamet Wiardi dengan tersangka Hamim Pou selaku Bupati dimana terjadi pengambialihan yang awalnya ditangani Kejaksanaan Negeri Suwawa ke Kejaksaan Tinggi Gorontalo.

Kedua, tersangka Yuldiawati Kadir dan Slamet Wiardi dilimpahkan ke Pengadilan Tindak Pidana Korupsi Gorontalo sedangkan tersangka Hamim Pou justru diterbitkan Surat Penghentian Penyidikan dan Penuntutan oleh Kejati Gorontalo. Ketiga, sampai sekarang kasus Hamim Pou selaku Bupati Aktif Bone Bolango belum dilimpahkan ke Pengadilan Tipikor Gorontalo, padahal sebagaimana amar putusan Mahkamah Agung menyebutkan Hamim Pou bersama dan berlanjut telah melakukan tindak pidana korupsi Dana Bansos APBD Bone Bolango tahun 2011-2012 dan diperkuat dengan Putusan Praperadilan Nomor 3/Pid.Pra Peradilan/2018/PN.GTO. Padahal terpidana lain sudah dieksekusi dan dimasukkan ke Lapas IIA Gorontalo.

Faktor morfologi sebagai variabel yang berpengaruh terhadap pengungkapan kasus Dana Bansos Bone Bolango sangat terlihat berpengaruh antara Kejaksaan Tinggi Gorontalo dengan tersangka Bupati Bone Bolango. Terlihat dari kedekatan persahabatan terkonfirmasi dari hadirnya tersangka Hamim Pou selaku Bupati Bone Bolango pada bulan Mei 2018 di Fakultas Hukum Universitas Airlangga Surabaya saat Kejati Gorontalo Firdaus Dawilmar Promosi Doktoral Ilmu Hukum. Sebelumnya, pada bulan Maret 2018 di Bandara Djalaluddin Gorontalo Firdaus Dawilmar berjumpa dengan petinggi Partai Nasdem yang sementara menyambut kedatangan Surya Paloh selaku Ketua Umum, dimana tersangka Hamim Pou merupakan Dewan Pimpinan Wilayah Partai Nasdem Provinsi Gorontalo.

Sejalan dengan kenyataan di atas, menurut Donald Black ${ }^{13}$, bahwa aspek morfologi sebagai aspek horizontal dari kehidupan sosial atau distribusi dari orangorang dalam hubungannya dengan orang lain, termasuk pembagian kerja di antara mereka, integrasi dan keakraban yang berlangsung di antara mereka, menunjukkan jarak hubungan atau derajat keakraban (relational distance) dalam interaksi antar

${ }^{13}$ Musakkir, ibid. hlm.189. 
Dialogia luridica: Jurnal Hukum Bisnis dan Investasi

Vol. 11 (1): 114-131

sesama. Aspek morfologi ini merupakan salah satu aspek variable yang sangat berpengaruh terhadap bekerjanya hukum di dalam kehidupan sosial.

3. Intervensi

Musakkir ${ }^{14}$ menambahkan faktor intervensi sebagai salah satu aspek sosiologis yang berpengaruh dalam penegakan hukum tindak pidana. Intervensi adalah campur tangan pihak internal lembaga penegak hukum. Campur tangan pihak internal kelembagaan dapat berupa tekanan pihak atasan kepada bawahan.

Faktor intervensi dapat terlihat dari pengambil alihan yang dilakukan oleh Kejaksaan Tinggi Gorontalo terhadap tersangka Hamim Pou yang sebelumnya ditangani oleh Kejaksaan Negeri Suwawa. Ujung dari intervensi ini adalah lahirnya Surat Penghentian Penyidikan dan Penuntutan (SP3) Nomor 509/R.5/Fd.1/09/2016 terhadap tersangka tindak pidana korupsi Dana Bansos APBD Bone Bolango.

\section{Rekonstruksi Pemberantasan Korupsi Politik di Daerah.}

Berdasarkan realitas penegakan hukum kasus korupsi Dana Hibah dan Bansos Jember dan Bansos Bone Bolango yang tergolong korupsi politik di daerah, maka ada beberapa hal yang menjadi catatan penulis. Pertama, diskriminasi penegak hukum sangat terlihat jelas dalam pengungkapan kedua kasus dana Bansos tersebut. Kedua, kasus korupsi dana Bansos yang tergolong korupsi politik yang melibatkan banyak pihak tidak terbongkar sampai tuntas dan masih banyak pihak-pihak sebagaimana yang disebutkan dalam putusan pengadilan justru belum tersentuh. Ketiga, pengungkapan tidak pidana korupsi yang berlarut-larut atau tidak efektif.

Oleh karena itu, Penulis mendorong perlunya rekonstruksi pemberantasan korupsi politik ke depan. Korupsi politik yang melibatkan pihak politisi dan pemangku kebijakan di daerah, tentu akan sangat sulit bila hanya ditangani secara biasa. Tindak pidana korupsi sebagai kejahatan luar biasa (extra ordinary crime), membutuhkan penanganan yang luarbiasa pula. Tanpa cara-cara luarbiasa jang berharap pemberantasan korupsi politik di daerah akan tuntas.

Cara luarbiasa yang dimaksud, antara lain. Pertama, dari sisi penegak hukum. mendorong reformasi penegak hukum di daerah. Reformasi penegak hukum yang menitik

${ }^{14}$ Musakkir, ibid. hlm.189-190. 
Dialogia luridica: Jurnal Hukum Bisnis dan Investasi

Vol. 11 (1): 114-131

beratkan pada pentingnya sistem rotasi kerja (rolling job) pada pucuk pimpinan di institusi penegak hukum. Dari sistem ini, selain menambah pengalaman, wawasan dan mengasah keterampilan. Di saat yang sama meminimalisir terciptanya aspek morfologi antara penegak hukum dengan elit-elit lokal.

Aspek morfologi sebagai aspek horizontal dari kehidupan sosial atau distribusi dari orang-orang dalam hubungannya dengan orang lain, termasuk pembagian kerja di antar mereka, menunjukkan jarak hubungan atau derajat keakraban (relation distance) dalam interaksi antar sesama. Aspek morfologi ini merupakan salah satu aspek variabel yang sangat berpengaruh terhadap bekerjanya hukum di dalam kehidupan sosial. ${ }^{15}$ Sudah menjadi rahasia umum, keakraban yang terjalin antara pimpinan penegak hukum dengan pimpinan Pemerintah Daerah dalam Forum Komunikasi Pimpinan Daerah (Forkompimda). Berdampak pada lemahnya penegakan hukum tindak pidana korupsi di daerah.

Kedua, dari sisi pengungkapan tindak pidana korupsi. Pelibatan saksi pelaku (justice collaborator) dalam mengungkap tindak pidana korupsi politik. Menurut Firman Wijaya $^{16}$ bahwa Justice Collaborator menjadi popular tatkala upaya pemberantasan korupsi membutuhkan terobosan hukum dalam pengungkapaan dan penuntasannya manakala kasus-kasus tersebut merupakan serious crime dan scandal crime. Skala yang meluas dan modus yang canggih dari kasus-kasus tersebut membutuhkan metode baru dan alat bantu dalam hukum pidana karena cara-cara konvensional dirasa sulit untuk mengungkap jenis kasus semacam ini.

Sejalan dengan Indriyanto Seno Adji ${ }^{17}$ mengemukakan dalam konteks komprehensif, tidak dapat dipungkiri lagi bahwa korupsi merupakan white collar crime dengan perbuatan yang selalu mengalami dinamisasi modus operandinya dari segala sisi sehingga dikatakan sebagai invisible crime yang sangat sulit memperoleh prosedural pembuktiannya.

Oleh karena itu, perkara sulitnya membuka modus operandi kejahatan terorganisir ini, dalam perkembangan penegak hukum ke depannya juga dilakukan dengan cara luar biasa.

\footnotetext{
${ }^{15}$ Musakkir, ibid. hlm. 189.

${ }^{16}$ Firma Wijaya, Whistle Blower dan Justice Collaborator dalam Prespektif Hukum, Jakarta: Penaku, 2012, hlm V.

${ }^{17}$ Indriyanto Seno Adji, Korupsi Kebijakan Aparatur Negara \& Hukum Pidana, Jakarta: Diadit Media, 2009, Hlm. 374.
} 
Terobosan yang diintrodusir dalam pembuktian kejahatannya, yakni dengan melalui pengungkapan kejahatan yang melibatkan pelaku kejahatan itu sendiri. Inilah yang disebut dengan saksi pelaku (Justice Collaborator). ${ }^{18}$

Efektivitas pengungkapan tindak pidana korupsi dengan melibatkan peran seorang Justice Collaborator, terkonfirmasi dalam penelitian yang dilakukan Amir Ilyas dan Jupri pada tahun 2018 (lihat tabel 2). ${ }^{19}$

Tabel 2.

Rincian Kasus Korupsi melibatkan Justice Collaborator yang dilakukan Komisi Pemberantasan Korupsi.

\begin{tabular}{|l|l|l|l|}
\hline No & \multicolumn{1}{|c|}{ Nama } & \multicolumn{1}{|c|}{$\begin{array}{c}\text { Jumlah } \\
\text { Terpidana }\end{array}$} & \multicolumn{1}{|c|}{ Kasus } \\
\hline 1 & AC & 30 orang & $\begin{array}{l}\text { Suap cek pelawat/ Pemilihan Deputi Gubernur } \\
\text { senior Bank Indonesia }\end{array}$ \\
\hline 2 & MRM & 5 orang & Wisma Atlet \\
\hline 3 & MRM & 1 orang & $\begin{array}{l}\text { Korupsi Pembangkit Listrik Tenaga Surya } \\
\text { Kementerian Tenaga Kerjaan dan Transmigrasi }\end{array}$ \\
\hline 4 & HS & 2 orang & $\begin{array}{l}\text { Pengadaan Vidiotron Kementerian Koperasi dan } \\
\text { Usaha Kecil Menegah }\end{array}$ \\
\hline 5 & FXYY & 4 orang & $\begin{array}{l}\text { Suap rekomendasi tukar-menukar kawasan hutan } \\
\text { di Kabupaten Bogor }\end{array}$ \\
\hline 7 & SS.B & 4 orang & Simulator SIM \\
\hline 8 & WM/MRM & 4 orang & $\begin{array}{l}\text { Korupsi Proyek Pengadaan Solar Home System } \\
\text { (SHS) }\end{array}$ \\
\hline
\end{tabular}

Sumber: Amir Ilyas \& Jupri, Justice Collaborator, GENTA Publishing, 2018.

Berdasarkan tabel 2 di atas, menunjukkan peran penting yang dilakukan Justice Collaborator dalam membantu penegak hukum membongkar kejahatan korupsi. Konsep Justice Collaborator ini juga diatur dalam Pasal 32 jo Pasal 37 United Nation Convention

\footnotetext{
${ }^{18}$ Amir Ilyas \& Jupri, Justice Collaborator; Strategi Mengungkap Tindak Pidana Korupsi, Yogyakarta: Genta Publishing. 2018, hlm. 48.

${ }^{19}$ Amir Ilyas \& Jupri, Ibid, hlm. 48-49.
} 
Dialogia luridica: Jurnal Hukum Bisnis dan Investasi

Vol. 11 (1): 114-131

Against Corruption, 2003. Sebagaimana diratifikasi menjadi Undang-Undang Nomor 7 Tahun 2006. Realitasnya, sampai saat ini hanya penyidik Komisi Pemberantasan Korupsi yang menerapkan pelibatan Justice Collaborator dalam mengungkap tindak pidana korupsi yang tergolong organized crime. Padahal pemberantasan tindak pidana korupsi melibatkan 3 (tiga) lembaga penegak hukum yakni Kepolisian, Kejaksaan dan Komisi Pemberantasan Korupsi.

Tanpa adanya upaya pelibatan Justice Collaborator, sudah tentu aparat penegak hukum akan mengalami kesulitan besar dalam membongkar organized crime. Hal ini disebabkan karena beberapa hal, Pertama tindak pidana semacam ini kerap dilakukan secara terorganisir. Kedua, para pelaku sama-sama diuntungkan dengan adanya tindak pidana sehingga sulit mengharapkan adanya laporan dari pihak yang dirugikan. Ketiga, pelaku tindak pidana tidak jarang melibatkan pihak yang memiliki kekuatan (kekuasaan/ jabatan, finansia, dan sebagainya) sehingga orang yang mengetahui tindak pidana tersebut takut untuk melaporkan kepada aparat penegak hukum. Keempat, pelaku mengetahui cara dan semakin canggih dalam menyembunyikan tindak pidana (transaksi dilakukan tunai, melakukan money laundering, melalui perantara, menghindari percakapan agar tidak terekam, dan sebagainya) sehingga tidak mudah untuk menemukan bukti-bukti tindak pidana tersebut. ${ }^{20}$

\section{PENUTUP}

Realitas penegakan hukum korupsi politik di daerah dalam hal ini terkait korupsi Dana Hibah dan Bantuan Sosial Jember dan Bone Bolango didominasi pemangku kekuasaan legislatif dan eksekutif. Pengungkapan kasus ini, sangatlah sulit karena aspek sosiologis berpengaruh dalam penegakan hukum seperti variabel Status Sosial (Stratification), Morfologi dan Intervensi. Status sosial yakni kedudukan formal atau jabatan yang dimiliki seseorang, kedekatan persahabatan antara penegak hukum dengan tersangka dan intervensi atasan terhadap bawahan dalam instansi penegak hukum. Mengkonfirmasi adanya diskriminasi hukum tindak pidana korupsi Dana Bansos di daerah.

Rekonstruksi pemberantasan korupsi politik musti segera dilakukan. Pengungkapan korupsi politik yang melilit sejumlah anggota DPRD dan Kepala Daerah, tidak bisa hanya

\footnotetext{
20 Lilik Mulyadi, Perlindungan Hukum Wistleblower \& Justice Collaborator Dalam Upaya Penanggulangan Organized Crime, Bandung: Alumni, 2015, hlm. 39.
} 
Dialogia luridica: Jurnal Hukum Bisnis dan Investasi

Vol. 11 (1): 114-131

ditangani dengan cara-cara biasa. Solusi yang ditawarkan yakni pertama, dari sisi kelembagaan penegak hukum. Penerapan sistem rotasi kerja (rolling job) bagi puncuk pimpinan penegak hukum agar tidak tercipta hubungan keakraban dengan unsur Muspida lainnya, yang berpotensi pada lemahnya penegakan hukum ke depan. Kedua, mendorong pelibatan peran aktif justice collaborator dalam mengungkap tindak pidana korupsi, yang sangat tertutup rapih dan rumit.

\section{DAFTAR PUSTAKA}

\section{Buku}

Achmad Ali, Menjelajahi Kajian Empiris Terhadap Hukum, Kencana, Jakarta, 1998

Agus Riwanto, Desain Sistem Pemerintahan Antikorupsi; Konsep Pencegahan Korupsi Politik dalam Sistem Pemerintahan, Partai Politik dan Pemilu, Malang: Setara Press, 2018

Amir Ilyas \& Jupri, Justice Collaborator; Strategi Mengungkap Tindak Pidana Korupsi, Yogyakarta: GENTA Publishing, 2018

Artidjo Alkostar, Korupsi Politik di Negara Modern, Yogyakarta: UII Press, 2008

Firma Wijaya, Whistle Blower dan Justice Collaborator dalam Prespektif Hukum, Jakarta: Penaku, 2012.

Indriyanto Seno Adji, Korupsi Kebijakan Aparatur Negara \& Hukum pidana, Jakarta: Diadit Media, 2009

Jupri, KPK \& Korupsi Kekuasaan. Pusat Kajian Inovasi Pemerintahan dan Kerjasama Antar Daerah, Malang: FISIP Universitas Brawijaya, 2016.

KPK, Buku Putih 8 Agenda Antikorupsi Bagi Presiden 2014-2019, Jakarta, 2014.

Lilik Mulyadi, Perlindungan Hukum Whistleblower \& Justice Collaborator Dalam Upaya Penanggulangan Organized Crime, Bandung: Alumni, 2015

Muhtar Haboddin, et.al, Memahami Kompleksitas Korupsi, Akar, Implikasi dan Solusi, Malang: FISIP Press Universitas Brawijaya, 2016.

Musakkir, Putusan Hakim Yang Diskriminatif dalam Perkara Pidana; Suatu Tinjauan Sosiologi Hukum dan Psikologi Hukum, Yogyakarta: Rangkang, 2013

Satjipto Rahardjo, Faktor-Faktor yang Mempengaruhi Penegakan Hukum, Jakarta: Rajawali,1986. 
Dialogia luridica: Jurnal Hukum Bisnis dan Investasi

Vol. 11 (1): 114-131

Wijayanto dan Ridwan Zachrie, Korupsi Mengorupsi Indonesia, Jakarta: Gramedia Pustaka Utama, 2009.

\section{Putusan Pengadilan}

Putusan Pengadilan Nomor 177/Pid.Sus.TPK/2018/PN. SBY.

Putusan Praperadilan Nomor 3/Pid.Pra Peradilan/2018/PN.GTO.

Putusan Mahkamah Agung Nomor 59 K/ PID.SUS/2017.

Putusan Praperadilan Nomor 1/Pid.Pra Peradilan/ 2017/PN.GTO 